\title{
腎移植患者におけるミコフェノール酸モフェチル投与量と
} サイトメガロウィルス感染及び下㾋発現との関係

\author{
戸田貴大, ${ }^{*, a}$ 元木 孝, ${ }^{a}$ 黒澤菜穂子, ${ }^{a}$ 大和田榮治, ${ }^{a}$ 阿知波一人, ${ }^{b}$ \\ 結城祥充, ${ }^{b}$ 唯野貢司, ${ }^{b}$ 高橋保志, ${ }^{b}$ 下田直彦, ${ }^{c}$ \\ 新藤純理, ${ }^{c}$ 原田 浩, ${ }^{c}$ 関 利盛, ${ }^{c}$ 平野哲夫 $c$
}

\section{The Relationship between Dose of Mycophenolate Mofetil and the Occurrence of Cytomegalovirus Infection and Diarrhea in Renal Transplant Recipients}

\author{
Takaki TodA, ${ }^{*, a}$ Takashi MotoKI,${ }^{a}$ Nahoko KUROSAWA, ${ }^{a}$ Eiji OwADA, ${ }^{a}$ Kazuhito ACHIWA, ${ }^{b}$ \\ Yoshimitsu YUhKI,${ }^{b}$ Kohji TAdano, ${ }^{b}$ Yasushi TAKahashi, ${ }^{b}$ Naohiko Shimoda, ${ }^{c}$ \\ Junri SHINDO, ${ }^{c}$ Hiroshi HARADA, ${ }^{c}$ Toshimori SEKI, ${ }^{c}$ and Tetsuo HIRANO ${ }^{c}$ \\ Department of Pharmacy, Hokkaido College of Pharmacy, ${ }^{a}$ 7-1 Katsuraoka-cho, Otaru 047-0264, Japan, \\ and Department of Pharmacy, ${ }^{b}$ and Department of Renal Transplantation, ${ }^{c}$ Sapporo City General \\ Hospital, 1-1 Kita-11-jo Nishi-13-chome, Chuo-ku, Sapporo 060-8604, Japan
}

(Received August 27, 2004; Accepted November 24, 2004; Published online November 29, 2004)

To establish guidelines for avoiding the side effects of mycophenolate mofetil (MMF) in renal transplant recipients with tacrolimus (TAC) -based immunosuppression, the relationship between the daily dose of MMF and the occurrence of side effects was analyzed in this study. The frequency of side effects was investigated retrospectively in 28 renal transplant recipients treated with immunosuppression (men 14 : women 14, age: $33.0 \pm 12.4$ years, weight: $50.9 \pm 10.7 \mathrm{~kg}$ ) . Cytomegalovirus (CMV) infection and diarrhea were the most frequent side effects in the early transplant phase (from transplantation to 3-month biopsy) in the recipients. In 18 recipients, excluding the recipients with risk factors for $\mathrm{CMV}$ infection (ABO-incompatible transplantation, donor $(+)$ /recipient $(-)$ CMV serostatus, etc.), no significant correlation was shown between the daily dose of MMF and the occurrence of CMV infection in the two-sample $t$-test. On the other hand, the daily dose in the diarrhea group $(33.2 \pm 4.3 \mathrm{mg} / \mathrm{kg} / \mathrm{day}, n=5)$ was significantly higher than that in the no-diarrhea group at 30 days $(28.4 \pm 3.7 \mathrm{mg} / \mathrm{kg} / \mathrm{day}, n=23, p<0.05)$ and 90 days $(25.7 \pm 4.4 \mathrm{mg} / \mathrm{kg} / \mathrm{day}, n=21$, $p<0.005)$ after transplantation, respectively. The receiver-operating characteristic (ROC) curve also revealed that the risk of diarrhea increased with a daily MMF dose higher than $30 \mathrm{mg} / \mathrm{kg} / \mathrm{day}$. In conclusion, to decrease the risk of diarrhea in the early transplant phase in renal transplant recipients with TAC-based immunosuppression, the daily dose of MMF should not be more than $30 \mathrm{mg} / \mathrm{kg} /$ day.

Key words — mycophenolate mofetil; diarrhea; cytomegalovirus infection; receiver-operating characteristic curve; side effect

緒 言

ミコフェノール酸モフェチル（MMF）は，腎移 植後の拒絶反応の予防にシクロスポリン（CYA） やタクロリムス（TAC）などのカルシニューリン 阻害薬，副腎皮質ステロイドなどと併用して用いら れる薬物である. MMF は，経口投与後，速やかか つほぼ完全に吸収され，活性代謝物のミコフェノー

$a$ 北海道薬科大学医療薬学科, $b$ 市立札幌病院薬剂部, $c$ 同腎移植科

e-mail: toda@hokuyakudai.ac.jp
ル酸（MPA）に加水分解される. ${ }^{1)} \mathrm{MPA}$ は， de novo プリン生合成経路の律速酵素であるイノシン モノホスフェイト脱水素酵素を不競合的, 可逆的か つ特異的に阻害することにより，免疫抑制効果を現 わす。 ${ }^{2)} \mathrm{MMF}$ の主な副作用には汎血球減少症，感 染, 消化器症状などがあり, 特に, サイトメガロウ ィルス $(\mathrm{CMV})$ 感染や下痢は他の免疫抑制薬と比 ベて発現頻度が高い. ${ }^{3,4)} \mathrm{CMV}$ はヘルペス属ウィル スの 1 つであり，感染により，発熱，倦意感，関節 痛, 汎血球減少症などの症状が現れる。一方, MMF による下痢の発現率は $13.2 \%$ (承認時) であ 
るが，水様便など比較的重度なものが多く，また， 実際に臨床で経験する頻度はより高いことが指摘さ れている。これら副作用は，ほとんどの場合， MMF の減量・休薬及び薬物療法により消失する. しかしながら，急速な減量は不十分な免疫抑制効果 による急性拒絶反応発現につながる恐れがある。し たがって，MMF 投与量と副作用発現との関係につ いて調査することは，移植後の免疫抑制療法におけ る患者の QOL 向上にとって非常に重要である．既 に，いくつかの研究グループから，MMF による副 作用発現と MMF 投与量, MPA 血中濃度あるいは

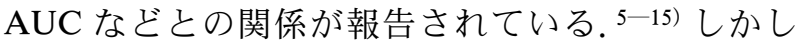
ながら，MMF 投与量と副作用発現の関係について 副作用毎に詳細に検討した報告は少ない.

そこで，今回われわれは，MMFによる副作用発 現を避けるための投与量ガイドラインを得るため,

$\mathrm{TAC}$ ，副腎皮質ステロイド，MMF による免疫抑制 療法を受けた腎移植患者を対象に，MMF に由来す ると考えられる副作用発現状況についてレトロスペ クティブに調査した。 さらに，調査の結果，発現頻 度が高かつた CMV 感染，下痢に関し，移植後初期 における MMF 投与量と副作用発現との関係につ いて検討した.

\section{方法}

1. 患者 2000 年 2 月一 2001 年 7 月に, 市立 札幌病院腎移植科において腎移植を受けたあと，免 疫抑制薬としてミコフェノール酸モフェチル（セル セプトカフプセ 250 ，中外製薬）を投与された患 者 28 名を対象とした。本研究の意義及び個人デー 夕の使用については，患者毎に説明し同意を得た. 対象患者の男女比は $14: 14$, 移植日時点での年齢 は $33.0 \pm 12.4(11-53)$ 歳, 体重は $50.9 \pm 10.7$ (37.6-72.5) kg であった。 また， 3 例は死体腎移植 であり，血液型不適合移植は 2 例， 2 次移植は 5 例 であった。主な原疾患は， IgA 腎症（7 例)，慢性 糸球体腎炎（6 例），巣状糸球体腎炎（FSGS）（4 例)，慢性腎不全（3 例）であった。また，CMVが Donor $(+)$ かつ Recipient $(-)$ の移植は 3 例であつ た。患者情報の詳細について Table 1 に示す。

2. 免疫抑制療法 対象患者 28 名すべてが移 植後の免疫抑制療法として TAC, 副腎皮質ステロ イド，MMF の投与を受けていた。 TAC, MMF は
Table 1. Characteristics of 28 Renal Transplant Recipients

\begin{tabular}{|c|c|}
\hline Gender (men : women) & $14: 14$ \\
\hline Age (years) & $33.0 \pm 12.4(11-53)$ \\
\hline Weight (kg) & $50.9 \pm 10.7(37.6-72.5)$ \\
\hline Transplant type (living : cadaveric) & $25: 3$ \\
\hline Age of donor (years) & $49.1 \pm 13.7(13-76)$ \\
\hline $\begin{array}{l}\text { ABO compatibility } \\
\text { (compatible : minor incompatible : } \\
\text { major incompatible) }\end{array}$ & $19: 7: 2$ \\
\hline HLA mismatch & 3 (mode) $(0-4)$ \\
\hline Second graft & 5 \\
\hline CMV Donor $(+) /$ Recipient $(-)$ & 3 \\
\hline \multicolumn{2}{|l|}{ Primary disease } \\
\hline IgA nephropathy & 7 \\
\hline Chronic glomerulonephritis & 6 \\
\hline Focal glomerulosclerosis & 4 \\
\hline Chronic renal failure & 3 \\
\hline Renal hypoplasia & 2 \\
\hline $\begin{array}{l}\text { Membranoproliferative } \\
\text { glomerulonephritis }\end{array}$ & 1 \\
\hline Polycystic kidney & 1 \\
\hline Nephrosis & 1 \\
\hline Postpartum renal failure & 1 \\
\hline Reflux nephropathy & 1 \\
\hline Unknown & 1 \\
\hline
\end{tabular}

Results are presented as the number, or mean \pm S.D. (range). CMV: cytomegalovirus.

8：00, 20：00の 1 日 2 回, 副腎皮質ステロイドは 8：00の 1 日 1 回投与された. 3 名の患者（膜性増 殖性糸球体腎炎（MPGN），FSGS，血液型不適合 移植各 1 名）は，移植後初期に抗リンパ球グロブリ ン（ALG）を加えた免疫抑制療法を行っており， CMV が Donor $(+) /$ Recipient (-)の 1 名は, CMV 感染の予防としてガンシクロビル $(\mathrm{GCV})$ を投与 されていた。移植後の MMF 服用開始時の投与量 は $1518 \pm 360(1000$-2000) mg/day, 体重当たりの 投与量は $29.8 \pm 3.9(24.7-38.5) \mathrm{mg} / \mathrm{kg} / \mathrm{day}$ であっ た。 $\mathrm{TAC}$ 投与量は, 術後 1 力月までは, トラフ值 $15-20 \mathrm{ng} / \mathrm{ml}, 1$ - 3 力月は $10-15 \mathrm{ng} / \mathrm{ml}, 3$ 力月 以降は 3-10 $\mathrm{ng} / \mathrm{ml}$ となるよう，コントロールされ ていた，副腎皮質ステロイドは，年齢及び体重に応 じてプレドニゾロン $40-60 \mathrm{mg} / \mathrm{day}$ で開始された 
のち，プロトコールに従い漸減され，プレドニゾロ ン又はメチルプレドニゾロンにより維持投与され た．拒絶反応発現時にはメチルプレドニゾロンのパ ルス療法及び塩酸グスペリムス（DSG）投与が行 われた。

3. 副作用発現 免疫抑制療法に関する薬歴, 臨床検査值, 副作用発現などの患者情報はカルテか ら得た。副作用の調査対象として，血液障害（白血 球減少, 貧血), 消化器症状 (下痢), 感染症 (CMV 感染，帯状疮疹)，手足のふるえ，脱毛，頻 脈を選択し，それぞれの副作用についてその発現頻 度及び発現時期（移植後日数）について調査した。 CMV 感染の判定にはアンチゲネミア法を用いた.

4. 解析方法 MMF 投与量と副作用発現との 関係を検討するに当たり，副作用には，発現頻度の 高かった CMV 感染及び下痢発現を選択した。ただ し，CMV 感染における対象患者は，CMV 感染リ スクファクターである血液型不適合移植患者 (2 名), CMV が donor (+)かつ recipient ( - ) 間での移植（3 名), 原疾患が FSGS, MPGN である患者（5名） を除いた 18 名とした.

CMV 感染においては，移植後 3 力月生検（移植 後 100 日前後）以内にアンチゲネミア法により白血 球中に CMV 抗原陽性細胞が検出され, かつ, GCV 投与による治療が行われた患者を CMV 感染 群とした。下痢発現においては，移植後 3 力月生検 以内に下痢を発現し，かつ，MMF が減量若しくは 休薬された患者を下痢発現群とした。 MMF 投与量 と副作用発現との関係は，投与量別発現頻度，two sample $t$-test 及び受診者動作特性分析曲線（Receiver-operating characteristic (ROC) カーブ) ${ }^{16)}$ にり 検討した。投与量別発現頻度においては，MMF1 回投与量 $(\mathrm{mg})$ 別に副作用発現頻度について調査 した. 1 回投与量は, 副作用発現群では発現時, 非 発現群では各患者における最大量とした。Two sample $t$-test においては，副作用発現群における発 現時の MMF1 日投与量 $(\mathrm{mg} / \mathrm{kg} / \mathrm{day})$ と, 副作用 非発現群における移植直後， 30 日後，90日後にお ける MMF1 日投与量について比較した。また，副 作用発現と腎機能との関係について検討するため, 患者のクレアチニンクリアランスについても比較し た。クレアチニンクリアランスには, CockcroftGault 法により推定した值を用いた，ROC カーブ
は，MMF1 日投与量を副作用発現のカットオフ值 としたときの感度を縦軸に，(1一特異度）を横軸に プロットすることにより作成し，曲線下面積から予 測指標の有効性を評価した。ささらに，副作用発現に 対する MMF1 日投与量の閾值を得るため，投与量 毎に陽性尤度比（二感度/(1一特異度)）を求めた。

ここで感度は, 副作用発現群においてカットオフ值 以上の MMF が投与されていた患者の割合，特異 度は, 副作用非発現群においてカットオフ值未満の MMF が投与されていた患者の割合を示している. すべての解析には, Microsoft Excel ${ }^{\circledR} 2000$ を用い, 有意水準は $p<0.05$ とした。

結果

1. 副作用発現頻度 免疫抑制療法中の副作用 発現頻度を Table 2 に示す。

MMF 服用中に, CMV 感染は 12 名に現れた。そ のうち, 移植後 3 力月生検までに CMV が検出され たのは 10 名であった。 また，GCV 投与が行われた のは 12 名中 10 名であった。下痢は 12 名に現れ た。そのうち, MMF が減量・休薬されたのは 7 名 であった。また，移植後 3 力月生検までに下痢が現 れた 6 名では，そのうち 5 名が MMFを減量・休 薬されていたのに対し，3 カ月以降に下痢が現れた 6 名中, MMF が減量・休薬されていたのは 2 名で あった. 白血球減少は移植後 3 力月生検以降に 4 名 に認められ，全員がMMFを減量されていた。帯 状疮疹は 3 力月生検後に 2 名に認められ, 2 名とも MMF は減量されていた。貧血は 2 名に認められ投 与初期に生じた 1 名で MMF が減量されていた。 手足のふるえは 4 名，頻脈は 3 名，脱毛は 3 名に認 められたが，いずれも MMF の減量は行われてい なかった。

2. 副作用発現と MMF 投与量との関係 現れ た副作用のうち, 発現頻度が高かった CMV 感染,

下痢発現について，その発現と MMF 投与量との 関係について検討した。これら副作用は，移植後初 期に起こりやすい結果が得られたことから，解析対 象期間は移植後 3 力月生検までとした。CMV 感染 の対象とした 18 名中, 移植後 3 力月生検以内に CMV に感染し，GCV 投与を受けた 7 名の患者を CMV 感染群, 残り 11 名を CMV 非感染群とし た。下痢発現に関しては，28 名中，移植後 3 力月 
Table 2. Side Effects of Mycophenolate Mofetil Found before and after 3-month Biopsy in 28 Renal Transplant Recipients Treated with Tacrolimus-based Immunosuppression

\begin{tabular}{|c|c|c|c|c|}
\hline & & \multicolumn{3}{|c|}{ The number of recipients } \\
\hline \multicolumn{2}{|c|}{ Side effects } & $\begin{array}{c}<3 \text {-month } \\
\text { biopsy }\end{array}$ & $\begin{array}{c}>3 \text {-month } \\
\text { biopsy }\end{array}$ & $\begin{array}{c}\text { Total } \\
(\%)\end{array}$ \\
\hline \multirow{2}{*}{$\begin{array}{l}\text { Hematological } \\
\text { disorders }\end{array}$} & Leucopenia & 0 & 4 & $4(14.3)$ \\
\hline & Anemia & 1 & 1 & $2(7.1)$ \\
\hline Digestive system & Diarrhea* & 6 & 6 & $12(42.9)$ \\
\hline \multirow{2}{*}{ Infectious diseases } & CMV infection** & 10 & 2 & $12(42.9)$ \\
\hline & Herpes zoster & 0 & 2 & $2(7.1)$ \\
\hline \multirow{3}{*}{ Others } & Tremor & 3 & 1 & $4(14.3)$ \\
\hline & Alopecia & 0 & 3 & $3(10.7)$ \\
\hline & Tachycardia & 2 & 1 & $3(10.7)$ \\
\hline
\end{tabular}

* The number of recipients treated with decrease or withdrawal of MMF was 7 ( 5 ; $<3$-month biopsy, 2 ; $>3$-month biopsy). ${ }^{* *}$ The number of recipients treated with injection of GCV was 10 (9; <3-month biopsy, 1 ; >3-month biopsy). MMF: mycophenolate mofetil, CMV: cytomegalovirus, GCV: ganciclovir.

Table 3. The Incidence of Cytomegalovirus Infection and Diarrhea

\begin{tabular}{cccc}
\hline \hline \multirow{2}{*}{ Side effects } & \multicolumn{3}{c}{ MMF dosage } \\
\cline { 2 - 4 } & $\begin{array}{c}500 \mathrm{mg} \\
(1000 \mathrm{mg} / \text { day })\end{array}$ & $\begin{array}{c}750 \mathrm{mg} \\
(1250-1500 \mathrm{mg} / \text { day })\end{array}$ & $\begin{array}{c}1000 \mathrm{mg} \\
(1750-2000 \mathrm{mg} / \text { day })\end{array}$ \\
\hline CMV infection $(n=18)$ & $2 / 2(100 \%)$ & $4 / 10(40 \%)$ & $1 / 6(17 \%)$ \\
\hline Diarrhea $(n=28)$ & $0 / 5(0 \%)$ & $2 / 13(15 \%)$ & $3 / 10(30 \%)$ \\
\hline
\end{tabular}

MMF: mycophenolate mofetil, CMV: cytomegalovirus.

生検以内に MMF の減量を伴う下痢を発現してい た 5 名を下痢発現群，残り 23 名を下痢非発現群と した。ただし，移植後 90 日における下痢非発現群 は，MMF 服用を中止されていた 2 名を除く 21 名 とした.

\section{2-1. 投与量別発現頻度まず初めに, MMF1} 回投与量別の副作用発現頻度について調査した. MMF1 回投与量は，500 mg (1000 mg/day)， 750 $\mathrm{mg}(1250-1500 \mathrm{mg} /$ day $), 1000 \mathrm{mg}(1750-2000$ $\mathrm{mg} /$ day）の 3 群に分けた。 その結果, CMV 感染 に関しては, 1 回投与量増加に伴う感染率上昇の傾 向は認められなかった。 これに対し，下痢発現では，

1 回投与量が増加するのに伴い, 発現率が上昇する 傾向が認められた（Table 3).

2-2. Two Sample $\boldsymbol{t}$-Test による解析つい で，副作用発現群と非発現群における体重当たりの MMF1 日投与量を two sample $t$-test により比較し た。 CMV 感染群における MMF1 日投与量は 26.9 $\pm 3.0(22.8-30.0) \mathrm{mg} / \mathrm{kg} /$ day であり, 非感染群の 投与量に対して有意な高值は示さず，むしろ移植直 後では非感染群の投与量の方が高值を示した $(p<$ 0.05)。一方，下痢発現では，下痢発現時の MMF1 日投与量 $33.2 \pm 4.3(30.2-40.5) \mathrm{mg} / \mathrm{kg} / \mathrm{day}$ は, 移 植直後では非発現群に対して有意差はなかったもの の, 移植 30 日後 $(28.4 \pm 3.7 \mathrm{mg} / \mathrm{kg} /$ day $), 90$ 日後 $(25.7 \pm 4.4 \mathrm{mg} / \mathrm{kg} /$ day $)$ に対しては有意に高值を認 めた（それぞれ $p<0.05, p<0.005) 。$ また，腎機能 に関しては，CMV 感染においては感染群と非感染 群との間に有意差は認められなかった。下痢発現に 関しては，CMV 感染と同様に有意差は認められな かったが，発現群におけるクレアチニンクリアラン スが若干低い傾向にあった（Table 4).

2-3. ROC カーブによる解析 CMV 感染につ いては，ROC カーブ，曲線下面積及び陽性尤度比 ともにほとんど相関は認められなかった。これに対 し下痢発現では，ROC 曲線下面積は，すべての移 
Table 4. The Daily Dose of Mycophenolate Mofetil and Creatinine Clearance in Cytomegalovirus Infection Group and Diarrhea Group

a. CMV infection

\begin{tabular}{rrrr}
\hline \hline & & MMF dose $(\mathrm{mg} / \mathrm{kg} / \mathrm{day})$ & $\mathrm{CCr}(\mathrm{ml} / \mathrm{min})$ \\
\hline \multirow{2}{*}{ CMV infection group $(n=7)$} & $26.9 \pm 3.0$ & $56.1 \pm 10.7$ \\
\hline \multirow{3}{*}{ No infection group } & 0 day after transplantation $(n=11)$ & $30.9 \pm 4.0^{*}$ & - \\
\cline { 2 - 4 } & 30 days after transplantation $(n=11)$ & $29.4 \pm 4.2$ & $58.4 \pm 16.5$ \\
\cline { 2 - 4 } & 90 days after transplantation $(n=11)$ & $26.6 \pm 4.8$ & $53.4 \pm 15.5$ \\
\hline
\end{tabular}

b. Diarrhea

\begin{tabular}{cccc}
\hline \hline & & MMF dose $(\mathrm{mg} / \mathrm{kg} / \mathrm{day})$ & $\mathrm{CCr}(\mathrm{ml} / \mathrm{min})$ \\
\hline & Diarrhea group $(n=5)$ & $33.2 \pm 4.3$ & $52.1 \pm 11.8$ \\
\hline \multirow{3}{*}{ No diarrhea group } & 0 day after transplantation $(n=23)$ & $29.4 \pm 3.9$ & - \\
\cline { 2 - 4 } & 30 days after transplantation $(n=23)$ & $28.4 \pm 3.7^{*}$ & $61.6 \pm 20.2$ \\
\cline { 2 - 4 } & 90 days after transplantation $(n=21)$ & $25.7 \pm 4.4^{* *}$ & $59.4 \pm 23.5$ \\
\hline
\end{tabular}

$* p<0.05 ; * * \quad p<0.005$, significantly different from the dose in side effect group. MMF: mycophenolate mofetil, CMV: cytomegalovirus, CCr: creatinine clearance.

植後日数で 0.7 以上となり, 陽性尤度比の最大值 は，移植後 90 日において MMF 投与量のカットオ フ值を $30 \mathrm{mg} / \mathrm{kg} /$ day としたときの 7.00 となっ た.さらに移植直後, 30 日後においても, カット オフ值 $30 \mathrm{mg} / \mathrm{kg} /$ day で陽性尤度比は 2 以上の值と なった（移植直後の尤度比 $=2.30,30$ 日後 $=2.88 ）$

(Figs. 1, 2).

\section{考察}

CMV はヘルペス属ウィルスの 1 つであり，日本 人の約 $90 \%$ で感染の既往歴がある，通常は治療の 必要はないが，移植後の免疫抑制薬投与に伴う再活 性化が原因で感染症を引き起こす。CMV 感染症は 免疫抑制薬の使用量が多い術後 1-4 力月以内に多 発し，通常は発熱を初発症状として発症，さらに肺 炎, 肝障害, 消化器潰瘍, 膵炎, 網膜炎などへ進展 し致命的となることもある．CMV 感染は腎移植患 者における慢性拒絶の原因 ${ }^{17)}$ となり，また，移植後 腎動脈狭窄の原因 ${ }^{18)}$ ともなることから，免疫抑制療 法を行う上で特に移植後初期での感染を防ぐことが 重要である。一方，MMF によるほとんどの消化器 系副作用は移植後 6 力月以内に発現する. MMF に よる消化器系副作用の明確な発現機序はいまだ明ら かになっていないが，局所での高い MPA 濃度が寄 与していると考えられている. ${ }^{19)}$ また, Wieland ら は，活性代謝物であるアシルグルクロナイドが，前
炎症物質サイトカインであるインターロイキン -6 と腫瘍壊死因子（TNF- $\alpha$ ) のヒト単核白血球から の放出を誘導することから，これらが消化管障害の 原因である可能性があると報告している. ${ }^{20)}$

今回われわれは，MMFによる副作用発現を避け るための投与量ガイドラインを得るため, TAC, 副腎皮質ステロイド, MMF の免疫抑制療法を受け た患者 28 名における副作用発現状況をレトロスペ クティブに調査した (Table 2)。その結果, CMV 感染，下痢発現の発現頻度が高い結果が得られた。 すなわち, MMF 服用中に, $\mathrm{CMV}$ 感染により $\mathrm{GCV}$ が投与された患者は 10 名（35.7\%）であり，その うち 9 名が移植後 3 力月生検までの感染であった。 一方，下痢は 12 名 (42.9\%) に認められ，このう ち MMF 減量を伴ったものは 7 名であった。

これらの発現頻度は大規模臨床試験による報 告21-23) と比べると若干高い。CMV 感染の頻度が 高い理由については不明であるが，患者のバックグ ラウンドや免疫抑制療法の違いなどが可能性として 考えられる．また，下痢発現については，われわれ の研究では移植後 1 年以降での発現も加えているこ とや，併用しているカルシニューリン阻害薬が CYA ではなく TACであることなどが理由として 考えられる。なお，これら以外の副作用発現頻度に 関しては，大規模臨床試験による報告21-23) とほぼ 同程度であった。 

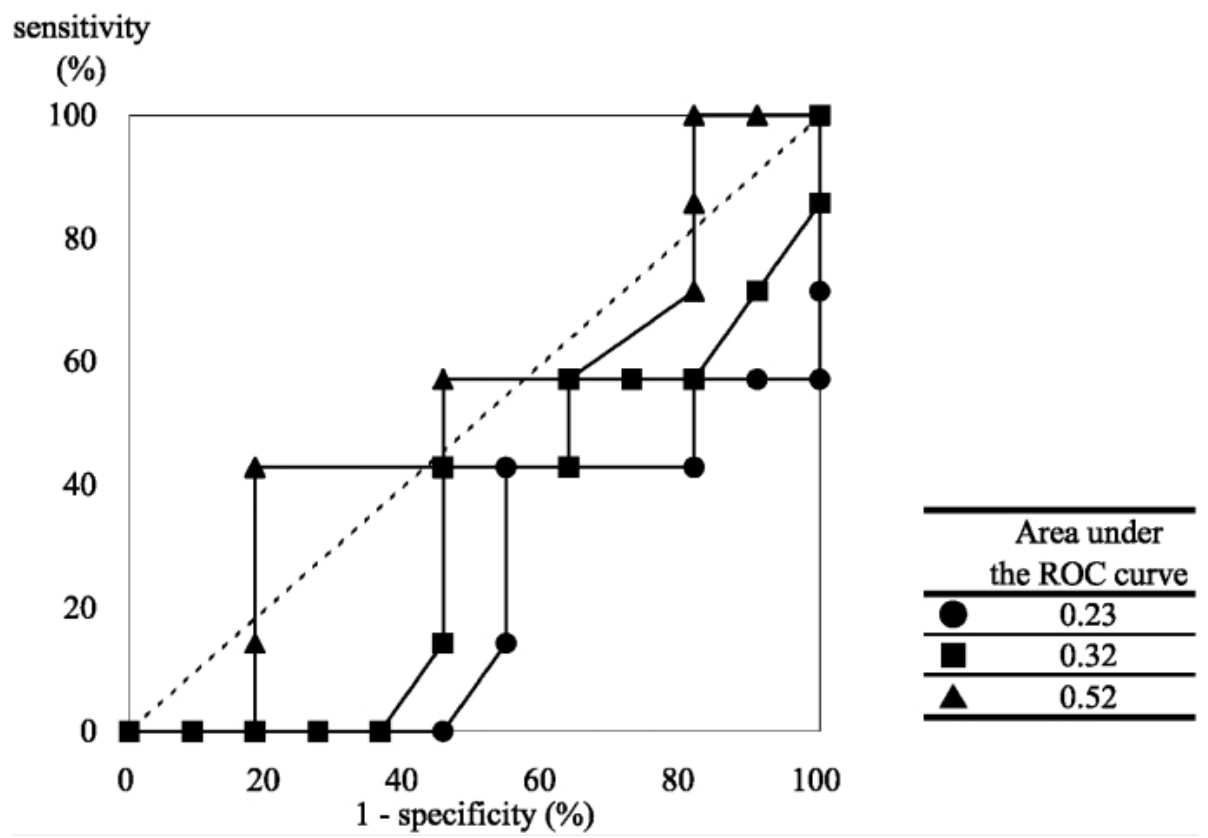

Fig. 1. Receiver-operating Characteristic (ROC) Curve Analysis of Association between the Daily Dose of Mycophenolate Mofetil and Cytomegalovirus Infection

: 0 day after transplantation, $\mathbf{\Delta}: 30$ days after transplantation, $\mathbf{\square}: 90$ days after transplantation. The dashed line represents the line of identity.
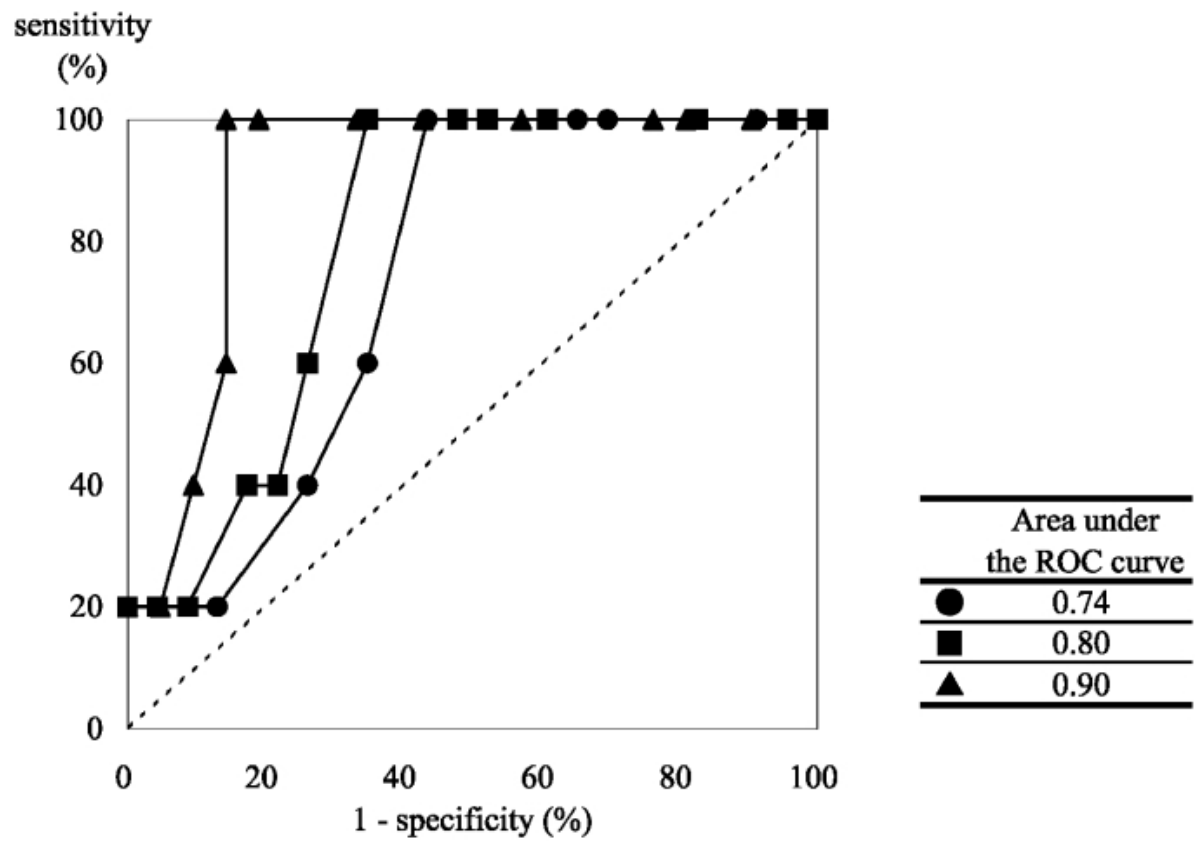

Fig. 2. Receiver-operating Characteristic (ROC) Curve Analysis of Association between the Daily Dose of Mycophenolate Mofetil and Diarrhea

: 0 day after transplantation, $\mathbf{\Delta}: 30$ days after transplantation,

90 days after transplantation, The dashed line represents the line of identity.

これまで, MMF による副作用の発現は, MMF 投与量や MPA 血中濃度, AUC との相関が報告さ れているが，いまだ闇值は明らかになっていな い.5)初期のコンセンサスでは MPA の AUC と副

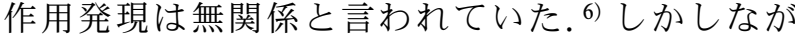
ら，対象とする副作用の種類によって得られる結果 は異なることが明らかになってきている，白血球減 少症や感染は MMF の免疫抑制効果に関わること 
から，MMF 投与量よりはむしろ MPA の濃度や AUC と相関があると考えられる，Kaplan らは，8 名の腎機能低下患者において, 白血球減少症を起こ した 4 名では遊離形 MPA の AUC が上昇傾向にあ ることを報告した. ${ }^{7)}$ Mourad らは，31 名の抗グロ ブリン抗体，CYA，副腎皮質ステロイド，MMF に よる免疫抑制療法を受けている腎移植患者において, MPA の AUC は副作用が現れた群で有意に高值を 示し, また, 服用 30 分後の平均 MPA 濃度は AUC 以上に有意差が強く現れることを報告した。この研 究における 21 名 25 回の副作用発現のうち, 多くは 白血球減少症（15 回）であり，下痢はわずか 1 回 しか含まれていない. ${ }^{8)}$ また，TAC 併用患者におけ る検討でも, 副作用発現と MPA 濃度との相関を報 告しているが，33 回の副作用のうち 19 回は血液障 害である. ${ }^{9)}$ Hubner らは，CYA，メチルプレドニ ゾロン，MMFによる免疫抑制療法を受けている 30 名の腎移植患者において, 副作用を生じた患者 における MMF 投与量は生じなかった群と有意差 がないにもかかわらず，MPAの投与直前濃度が有 意に高かったことを報告した。この研究における副 作用の多くは感染であり，消化管障害は含まれてい ない. ${ }^{10)}$ また，本邦においても，Takahashi らが,

CYA，副腎皮質ステロイド，MMF の 3 剂併用療法 を受けている日本人腎移植患者における検討で,

MPA の AUC が $90 \mu \mathrm{g} \cdot \mathrm{hr} / \mathrm{ml}$ 以上で過㮃な免疫抑 制による CMV 感染が起こり易くなることを報告し

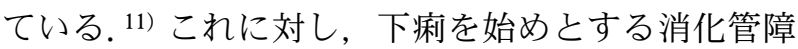
害は，MPAの全身暴露量ではなく，局所濃度と相 関があると考えられている19)ことから，MMF 投与 量との相関が考えられる。 Pillans らは，CYA，プ レドニゾン，MMFによる免疫抑制療法を受けた 27 名の腎移植患者において，消化管障害を生じた 4 名の MPA の AUC が有意に低值を示すことを報告 し，その原因として吸収不良による局所濃度の上昇 を挙げている. ${ }^{12)}$ Van Gelder らは，ロジスティック 解析により, 平均 MMF 投与量と副作用（下痢, 吐き気，胃痛）による MMF 服用中止との間に有 意差が認められたが，MPA 血中濃度の投与直前値 や Cmax, AUC の中央值との間には有意差はない ことを報告した。 ${ }^{13)}$ Hale らも，下痢発現と MMF 投与量との相関を報告している. ${ }^{14)}$ さらに, Weber らによる小児腎移植患者を対象とした研究では，遊
離形 MPA の AUC 又は最高血中濃度（Cmax）で 白血球減少症又は感染を発症した患者を区別できる が，下痢発現はすべての MPA に関する pharmacokinetic パラメータと関連がないことを報告し ている. ${ }^{15)}$

これらの結果から，MMF 投与量と副作用発現と の関係について検討するためには，副作用ごとに解 析する必要があることが明らかである。そこで，調 査対象とした副作用のうち，発現頻度が高かった CMV 感染，下痢発現について，移植後初期（移植 後 3 力月生検まで）のその発現と MMF 投与量と の関係を, 投与量別発現頻度, two sample $t$-test 及 びROC カーブを用いて検討した。 ROC カーブ は，臨床的予測指標の有効性判定に用いられる 1 つ の手法である. ROC カーブは, カットオフ值とし て選択した因子（今回は MMF1 日投与量）が臨床 的予測指標として優れているほど，左上に膨らんだ 曲線となる。一般的に曲線下面積が 0.7 以上で選択 因子がよい予測指標であり，0.85 以上で優れた予 測指標であると言われている. ${ }^{24)}$ また，陽性尤度比 は感度/（1一特異度）で表され，副作用発現群にお いて MMF1 日投与量がカットオフ值以上である患 者の割合が，非発現群においてカットオフ值以上で ある患者の割合に対しどれだけ高いかを示す指標で ある。一般的に， 2 以上でカットオフ值以上におけ る発現率の上昇を軽度に， 5 以上で中程度に，10 以 上で高度に示唆すると言われている. ${ }^{25)}$

CMV 感染については，1 回投与量別の副作用発 現頻度において，投与量増量と感染率増加との間に 関係は認められなかった（Table 3)。また，副作用 発現群と非発現群における MMF1 日投与量による two sample $t$-test の結果においても，CMV 感染群 における MMF1 日投与量は, 非感染群の投与量に 対し有意な高值を示さなかった (Table 4).さらに, ROC カーブによる解析においても, 曲線下面積か ら，副作用発現とMMF 投与量との間にほとんど 相関は認められなかつた（Fig. 1)。MMF 投与量と CMV 感染との間に関連性が認められなかったのは, MMF は CMV 感染の 1 つの要因であるが，既に述 べたように CMV 感染の危険性を判断するには, MMF 投与量より MPA の血中濃度や AUC が適し ていると考えられること, 及び併用する免疫抑制薬 の種類，投与量，血中濃度，AUCなどについても 
考慮する必要性があることを示していると思われる.

一方，下痢発現については，例数が少ないために 有意差検定はできなかつたものの，1 回投与量別の 副作用発現頻度において，投与量が増えるに従い発 現率が上昇する傾向が認められた(Table 3)。また, two sample $t$-test において，下痢発現群の MMF 投 与量 $33.2 \pm 4.3 \mathrm{mg} / \mathrm{kg} / \mathrm{day}$ は，非発現群の MMF 投 与量に対し, 移植直後では有意差はなかったもの の, 移植 30 日後 $(28.4 \pm 3.7 \mathrm{mg} / \mathrm{kg} /$ day $), 90$ 日後 $(25.7 \pm 4.4 \mathrm{mg} / \mathrm{kg} /$ day $)$ に対して有意に高いことが 認められた（それぞれ $p<0.05, p<0.005 ） （$ Table 4)。したがって，MMF による下痢発現は MMF 投 与量と関連性のあることが示唆された．移植後日数 が経過するにつれてより強い有意差が認められるよ うになつたのは，患者の容態を観察しながら MMF が減量されているためと考えられる。ささらに，Fig. 2 に示したように，下痢発現の MMF 投与量に対す る ROC 曲線は左上に膨らみ，曲線下面積は，臨床 的予測のよい指標であることを表す 0.7 以上となつ た。さらに，各カットオフ值における陽性尤度比を 求めたところ, MMF1 日投与量のカットオフ值を $30 \mathrm{mg} / \mathrm{kg} /$ day としたときに, すべての移植後日数 において陽性尤度比が下痢発現の危険性上昇を示唆 する 2 以上となった（移植直後：2.30，移植 30 日 後: 2.88 , 移植 90 日後: 7.00). したがって, TAC，副腎皮質ステロイド, MMF による免疫抑制 療法を受けている腎移植患者においては，MMF1 日投与量を $30 \mathrm{mg} / \mathrm{kg} / \mathrm{day}$ 未満に設定することで, 移植後初期の下痢発現リスクを軽減できることが示 唆された。セルセプト®の添付文書では，腎移植に おける拒絶反応抑制のための投与量は $2000 \mathrm{mg} /$ day となっている。しかしながら，今回の結果からみる と， $65 \mathrm{~kg}$ 未満の患者においてはこの投与量は若干 多めであり，下痢発現を避けるためには適宜少ない 投与量から開始することが有効であると考えられ る。また，今回対象とした腎移植患者のうち，移植 90 日後までに急性拒絶反応を起こした患者は 4 名 であり，そのときの MMF 投与量は 23.4-28.0 mg $/ \mathrm{kg} / \mathrm{day}$ であった．急性拒絶反応抑制は MMF 投与 量のみで決まる訳ではないが，下痢発現を回避する ために MMF を $30 \mathrm{mg} / \mathrm{kg} / \mathrm{day}$ で投与することで急 性拒絶のリスクが上昇する可能性は低いと考えられ る.
既に述べたように，MMFによる消化器系副作用 の原因の 1 つとして，局所での高い MPA 濃度が考 えられている. ${ }^{19)}$ MMF は経口投与後 MPA となつ たのち，その多くは，グルクロノシルトランスフェ ラーゼによりフェノール性グルクロナイドの不活性 代謝物（MPAG）に代謝される．MPAG は大部分 が腎から排泄されるが，一部は，胆汁排泄後，腸肝 循環を受けMPA となり再吸収される.11)したがつ て，腎機能が低下している患者においては， MPAG が体内に蓄積し胆汁排泄される MPAG が 増え，その結果腸内 MPA 濃度が上昇し下痢を発現 し易くなる可能性が考えられる。 また，再吸収され る MPA が増えることで MPA の AUCが上昇し, $\mathrm{CMV}$ 感染を起こし易くなる可能性もある。そこ で, 患者の血清クレアチニン值からクレアチニンク リアランスを推定し，副作用発現群と非発現群にお いて比較することにより，副作用発現における腎機 能低下の影響について検討した。その結果，CMV 感染においてはクレアチニンクリアランスに群間の 差はほとんどなかったのに対し，下痢発現において は，有意差はないものの発現群において若干クレア チニンクリアランスが低い傾向にあった（Table 4)。また，下痢発現群の 1 名においては，下痢発現 時にクレアチニンクリアランスが大きく低下（非発 現時 : $83.3 \mathrm{ml} / \mathrm{min}$, 発現時 : $48.8 \mathrm{ml} / \mathrm{min}$ ) してい た。さらに，最近 Kobayashi らは，ラットを用い た実験により，胆汁排泄された MPAG そのものが MMF による下痢の一因となる説を提唱した. ${ }^{26)} し$ たがってこれらの結果より，腎機能低下時には急性 拒絶反応のみならず MMF による副作用（特に下 痢）発現に関しても慎重な観察が必要であると思わ れる。

結論として，今回の検討により，腎移植後に TAC，副腎皮質ステロイド，MMFによる免疫抑制 療法を受ける患者において，MMF による移植後初 期の下痢発現を防ぎ，かつ，免疫抑制効果を最大限 に得るためには，初期投与量を $30 \mathrm{mg} / \mathrm{kg} /$ day で開 始すればよいことが明らかとなった。また，CMV 感染に関しては，MMF 投与量との相関が認められ なかった。したがって，免疫抑制療法中に CMV 感 染を生じた場合には，MMF を含めた免疫抑制薬の 減量，休薬や，GCV 投与などで速やかに対応すべ きである。また，MMF による CMV 感染を防ぐた 
めには，可能であれば，カルシニューリン阻害薬の

みならず，MPAの血中濃度測定さらには limited sampling strategy による AUC 推定5,27) を考慮すべ きと考える。

\section{REFERENCES}

1) Bullingham R. E., Nichollis A. J., Kamm B. R., Clin. Pharmacokinet., 34, 429-455 (1998).

2) Ransom J. T., Ther. Drug Monit., 17, 681684 (1995).

3) Lipsky J. L., Lancet, 348, 1357-1359 (1996).

4) Sarmiento J. M., Dockrell D. H., Schwab T. R., Munn S. R., Paya C. V., Clin. Transplant., 14, 136-138 (2000).

5) Cox V. C., Ensom M. H., Ther. Drug Monit., 25, 137-157 (2003).

6) Shaw L. M., Sollinger H. W., Halloran P., Morris R. E., Yatscoff R. W., Ransom J., Tsina I., Keown P., Holt D. W., Lieberman R., Jaklitsch A., Potter J., Ther. Drug Monit., 17, 690-699 (1995).

7) Kaplan B., Meier-Kriesche H. U., Friedman G., Mulgaonkar S., Gruber S., Korecka M., Brayman K. L., Shaw L. M., J. Clin. Pharmacol., 39, 715-720 (1999).

8) Mourad M., Malaise J., Chaib Eddour D., De Meyer M., Konig J., Schepers R., Squifflet J. P., Wallemacq P., Clin. Chem., 47, 88-94 (2001).

9) Mourad M., Malaise J., Chaib Eddour D., De Meyer M., Konig J., Schepers R., Squifflet J. P., Wallemacq P., Clin. Chem., 47, 12411248 (2001).

10) Hubner G. I., Eismann R., Sziegoleit W., $A r$ zeim.-Forsch., 50, 936-940 (2000).

11) Takahashi K., Ochiai T., Uchida K., Yasumura T., Ishibashi M., Suzuki S., Otsubo O., Isono K., Takagi H., Oka T., Okuyama A., Sonoda T., Amemiya H., Ota K., Transplant. Proc., 27, 1421-1424 (1995).

12) Pillans P. I., Rigby R. J., Kubler P., Willis C., Salm P., Tett S. E., Taylor P. J., Clin. Biochem., 34, 77-81 (2001).

13) van Gelder T., Hilbrands L. B., Vanrenter- ghem Y., Weimar W., de Fijter J. W., Squifflet J. P., Hene R. J., Verpooten G. A., Navarro M. T., Hale M. D., Nicholls A. J., Transplantation, 68, 261-266 (1999) .

14) Hale M. D., Nicholls A. J., Bullingham R. E., Hene R., Hoitsma A., Squifflet J. P., Weimar W., Vanrenterghem Y., Van de Woude F. J., Verpooten G. A., Clin. Pharmacol. Ther., 64, 672-683 (1998).

15) Weber L. T., Shipkova M., Armstrong V. W., Wagner N., Schutz E., Mehls O., Zimmerhackl L. B., Oellerich M., Tonshoff B., $J$. Am. Soc. Nephrol.,13, 759-768 (2002).

16) Zweig M. H., Campbell G., Clin. Chem., 39, 561-577 (1993).

17) Humar A., Gillingham K. J., Payne W. D., Dunn D. L., Sutherland D. E., Matas A. J., Transplantation, 68, 1879-1883 (1999).

18) Pouria S., State O. I., Wong W., Hendry B. M., QJM., 91, 185-189 (1998) .

19) Behrend M., Drug Saf., 24, 645-663 (2001).

20) Wieland E., Shipkova M., Schellhaas U., Schutz E., Niedmann P. D., Armstrong V. W., Oellerich M., Clin. Biochem., 33, 107-113 (2000).

21) Sollinger H. W., Transplantation, 60, 225-232 (1995).

22) The Tricontinental Mycophenolate Mofetil Renal Transplantation Study Group, Transplantation, 61, 1029-1037 (1996).

23) European Mycophenolate Mofetil Cooperative Study Group, Lancet, 345, 1321-1325 (1995).

24) Swets J. A., Science, 240, 1285-1293 (1988).

25) Sackett D. L., Straus S. E., Richardson W. S., Rosenberg W., Haynes R. B., "EvidenceBased Medicine: How to Practice and Teach EBM.," Churchill Livingstone, London, 1997.

26) Kobayashi Mik., Saitoh H., Kobayashi Mic., Tadano K., Takahashi Y., Hirano T., J. Pharmacol. Exp. Ther., 309, 1029-1035 (2004).

27) Toda T., Watanabe H., Kurosawa N., Owada E., Achiwa K., Yuhki Y., Tadano K., Takahashi Y., Harada H., Seki T., Hirano T., Jpn. J. Pharm. Health Care Sci., 30, 1-7 (2004) . 